\title{
Analysis of electric motor vehicles market
}

The increasingly restrictive standards related to exhaust emissions from cars make difficult the development of internal combustion engines. The activities undertaken in the design of internal combustion engines are mainly based on downsizing, e.g decreasing the engine's displacement. The main direction in the development of vehicle propulsion is to reduce carbon dioxide emissions. It is expected to reduce $\mathrm{CO}_{2}$ emissions in 2020 to reach $95 \mathrm{~g} / \mathrm{km}$. Electric vehicles achieve low noise levels and do not emitted a burn, and thus, their use leads to a reduction in the amount of toxic exhaust gases in the air. The aspect of reducing emissions of harmful exhaust compounds and activities focusing on downsizing on the market of combustion engine cars leads to a significant increase the number of electric vehicles. In 2018 around 95 million motor vehicles were registered in the world, of which around 12 million in the European Union and 273 thousand in Poland. The number of electric vehicles among all sold is around 5.5\%. Every year new, more technologically advanced models appear on the electric vehicle market. In 2018, the most popular model was the Nissan LEAF and the BAIC EC-Series. A large number of Renault ZOE have also been sold. In article analyzed different models of electric vehicle, which are available on market and presented the characteristics based on e.g. price per 100 kilometers, range for every model or charging time.

Key words: electric propulsion market, toxic exhaust emission, costs of charging electric vehicle

\section{Introduction}

The increasingly restrictive standards related to exhaust emissions $[14,16]$ from cars make difficult the development of internal combustion engines. The activities undertaken in the design of internal combustion engines are mainly based on downsizing, which means decreasing the engine's displacement. The main direction in the development of vehicle drives is to reduce carbon dioxide emissions. It is expected that the $2020 \mathrm{CO}_{2}$ emission reduction will reach $95 \mathrm{~g} / \mathrm{km}$ [1]. When analyzing, the market for electric vehicles with electric propulsion, at first the construction of such a propulsion should be known (Fig. 1). The electric drive consists of such elements as: the drive accumulator, engine, tachometer, vehicle network battery, power unit and control unit, converter [3].

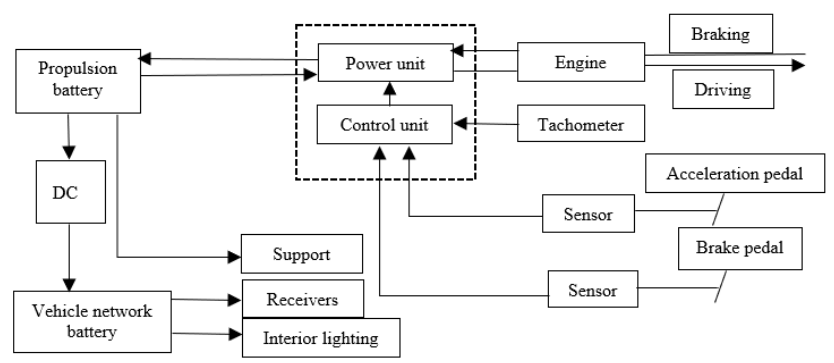

Fig. 1. The scheme of configuration motor vehicle with electric propulsion [3]

The use of electric propulsion lead to achieves low noise levels and do not emit a toxic exhaust emission, and thus, their use leads to a reduction in the amount of toxic exhaust gases in the air. The aspect of reducing emissions of harmful exhaust compounds and activities focusing on downsizing, on the market for combustion cars, leads to a significant increase in the pace of development of electric drives, not only passenger cars, but also various types of aircraft and yachts. In 2018 alone (Fig. 2) $49.1 \%$ cars registered in Norway was electric cars, in Iceland it was $19.1 \%$.
The biggest market of electric vehicles are China and USA [2].

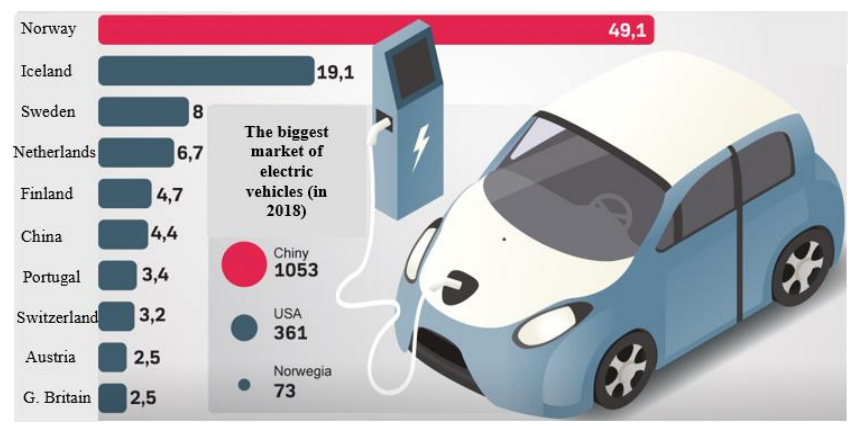

Fig. 2. The part of electric cars in new car registrations in 2018 [2]

The percentage division of fully electric cars among those registered by November in 2018 is shown in Fig. 3.

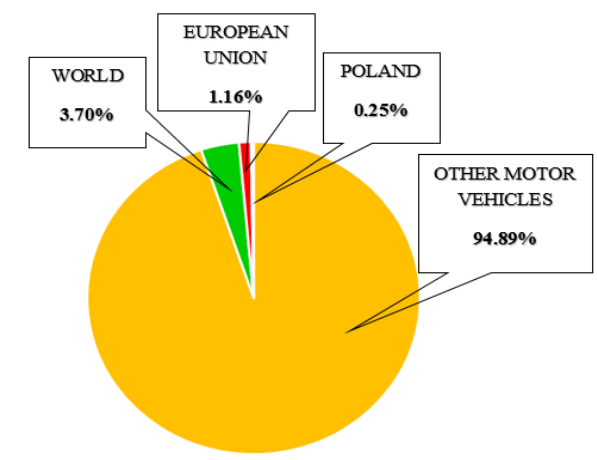

Fig. 3. Percentage part of fully electric cars among those registered by November 2018

Can be seen the number of electric vehicles of all sold cars is around 5.5\%. In the European Union, around $1.16 \%$ of them were sold, where the largest number of fully electric vehicles were registered in Norway. Every year new, more technologically advanced models appear on the elec- 
tric vehicle market. In 2018, the most popular unit was the Nissan LEAF. A large number of Renault ZOE have also been sold. This model has been eagerly bought in Poland, mainly due to belonging to the car sharing system Traficar.

\section{The most modern solutions for electric cars}

The latest models of cars with electric propulsion available on the market in 2019 include Hyundai KONA electric (Fig. 4). The Hyundai company was founded in 1967 and is a South Korean automotive group. This model is a Sport Utility Vehicle (SUV) with electric propulsion.

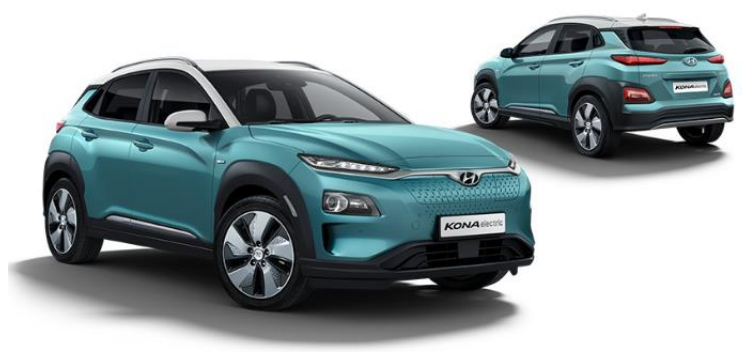

Fig. 4. Hyundai KONA electric [5]

Data regarding the electric drive are shown in Table 1. As can be seen (on the basis of Table 1) Hyundai KONA electric has a very large range and battery capacity with fast charging (up to $80 \%$ ). In about an hour, charging with a high voltage charger can reach a range of about $300 \mathrm{~km}$. The maximum speed that this car model can reach is about $170 \mathrm{~km} / \mathrm{h}$. This vehicle develops a speed of $100 \mathrm{~km} / \mathrm{h}$ in less than 8 seconds.

Table 1. Technical data for Hyundai KONA electric [5]

\begin{tabular}{|l|c|}
\hline Type of data & Value \\
\hline Battery capacity & $64 \mathrm{kWh}$ \\
\hline Maximum power & $204 \mathrm{hp}$ \\
\hline Maximum velocity & $167 \mathrm{~km} / \mathrm{h}$ \\
\hline Acceleration $(0-100 \mathrm{~km} / \mathrm{h})$ & $7.6 \mathrm{~s}$ \\
\hline Time of fast charging & $54 \mathrm{~min}$ \\
\hline Time of normal charging & $9 \mathrm{~h} 40 \mathrm{~min}$ \\
\hline Range & $470 \mathrm{~km}$ \\
\hline
\end{tabular}

One of the most popular electric cars bought in 2018 was Renault ZOE (Fig. 5). It is a car often using in cities, as Traficar (car sharing system in Poland), which is a car rented for a minute's drive. This form of Renault ZOE is from August 2018. The based data concerns this model of car are performed in Table 2.

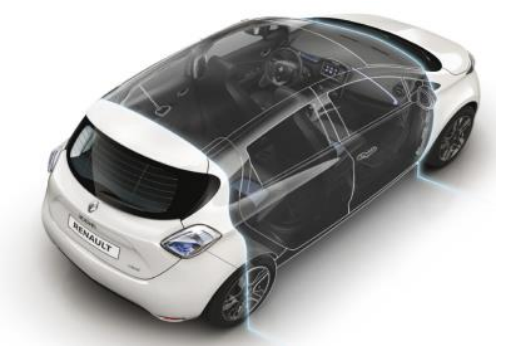

Fig. 5. Renault ZOE [6]
Analyzing Table 2, it can be concluded that the discussed model is a small unit $(4.084 \mathrm{~m} / 1.95 \mathrm{~m} / 1.5 \mathrm{~m})$. It is a car vehicle suitable mainly for moving around the city, but it also provides a range of up to around $300 \mathrm{~km}$ (Table 2 ). The possibility of fast charging ensures a charge up to $(80 \%)$ in about 2 hours. Renault ZOE is a vehicle mainly used for urban driving. The maximum speed that this model can reach $135 \mathrm{~km} / \mathrm{h}$. The disadvantage of this vehicle is that acceleration to $100 \mathrm{~km} / \mathrm{h}$ takes about 13 seconds.

Table 2. Technical data for Renault ZOE [6]

\begin{tabular}{|l|c|}
\hline Type of data & Value \\
\hline Battery capacity & $41 \mathrm{kWh}$ \\
\hline Maximum power & $92 \mathrm{hp}$ \\
\hline Maximum velocity & $135 \mathrm{~km} / \mathrm{h}$ \\
\hline Acceleration $(0-100 \mathrm{~km} / \mathrm{h})$ & $13.2 \mathrm{~s}$ \\
\hline Time of fast charging & $1 \mathrm{~h} 40 \mathrm{~min}$ \\
\hline Time of normal charging & $7 \mathrm{~h} 25 \mathrm{~min}$ \\
\hline Range & $300 \mathrm{~km}$ \\
\hline
\end{tabular}

When reviewing the market for motor vehicles with fully electric drive, it is necessary to characterize the unit, which in 2018 was the most frequently purchased electric car. In the same year, around 42,000 Nissan LEAF models were sold (Fig. 6).

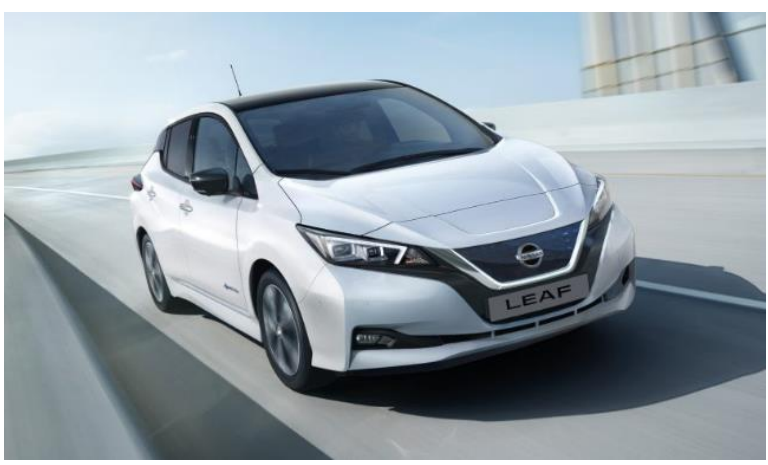

Fig. 6. Nissan LEAF [7]

Table 3 summarizes the basic technical data for the vehicle. It is a model with a capacity of $40 \mathrm{kWh}$ batteries and a range of $380 \mathrm{~km}$. The obtained power is about $150 \mathrm{hp}$. Up to $80 \%$ can be charged in 60 minutes using a high voltage charger (at least $40 \mathrm{~kW}$ ). The maximum speed that this vehicle can reach is $140 \mathrm{~km} / \mathrm{h}$ and up to $100 \mathrm{~km} / \mathrm{h}$ accelerates in less than 8 seconds.

Table 3. Technical data for Nissan LEAF [7]

\begin{tabular}{|l|c|}
\hline Type of data & Value \\
\hline Battery capacity & $40 \mathrm{kWh}$ \\
\hline Maximum power & $150 \mathrm{hp}$ \\
\hline Maximum velocity & $140 \mathrm{~km} / \mathrm{h}$ \\
\hline Acceleration $(0-100 \mathrm{~km} / \mathrm{h})$ & $7.9 \mathrm{~s}$ \\
\hline Time of fast charging & $60 \mathrm{~min}$ \\
\hline Time of normal charging & $6 \mathrm{~h} 30 \mathrm{~min}$ \\
\hline Range & $380 \mathrm{~km}$ \\
\hline
\end{tabular}

In 2018, on the market of fully electric motor vehicles, also e-GOLF occur (Fig. 7). It is one of two models of cars with electric propulsion produced by Volkswagen. 


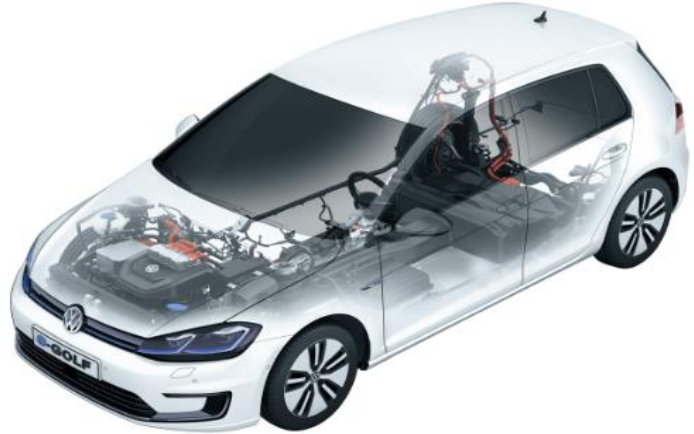

Fig. 7. Volkswagen e-GOLF [8]

The basic technical data on the Volkswagen e-GOLF vehicle drive is shown in table 4 . This model has $36 \mathrm{kWh}$ batteries, which deliver $134 \mathrm{hp}$ to the drive. Using the quick-charger chargers most often available in Poland (charging $40 \mathrm{~kW}$ ), we will charge the car up to $80 \%$ in about an hour. The maximum speed that the drive starts is $150 \mathrm{~km} / \mathrm{h}$. On the other hand, reaching $100 \mathrm{~km} / \mathrm{h}$ takes about 10 seconds.

Table 4. Technical data for Volkswagen e-GOLF [8]

\begin{tabular}{|l|c|}
\hline Type of data & Value \\
\hline Battery capacity & $36 \mathrm{kWh}$ \\
\hline Maximum power & $134 \mathrm{hp}$ \\
\hline Maximum velocity & $150 \mathrm{~km} / \mathrm{h}$ \\
\hline Acceleration $(0-100 \mathrm{~km} / \mathrm{h})$ & $9.6 \mathrm{~s}$ \\
\hline Time of fast charging & $60 \mathrm{~min}$ \\
\hline Time of normal charging & $6 \mathrm{~h}$ \\
\hline Range & $300 \mathrm{~km}$ \\
\hline
\end{tabular}

The next analyzed model is Audi e-TRON (Figure 8). The Audi company is a German car manufacturer belonging to the Volkswagen group. The company was founded in 1909. The premiere of this electric car model in Poland took place in November 2018. This vehicle has a fully electric propulsion and is a SUV. The e-TRON model is the first electric car released by Audi.

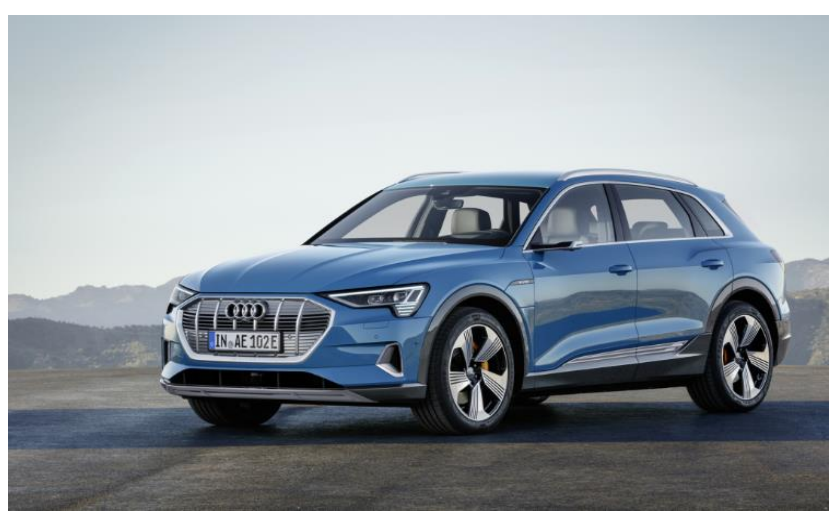

Fig. 8. Audi e-TRON [9]

Table 5 contains the technical data. Audi e-TRON has a battery with a very large capacity $-95 \mathrm{kWh}$. This car with fully charged batteries reaches a range up to $400 \mathrm{~km}$. The obtained power is up to $408 \mathrm{hp}$. The maximum speed that a vehicle can reach is $200 \mathrm{~km} / \mathrm{h}$. The Audi model reaches speed of $100 \mathrm{~km} / \mathrm{h}$ in 6 seconds. The disadvantage of the car is the charging time, because the basic charger, available on Polish stations can be charged up to 5 hours.

Table 5. Technical data for Audi e-TRON [9]

\begin{tabular}{|l|c|}
\hline Type of data & Value \\
\hline Battery capacity & $95 \mathrm{kWh}$ \\
\hline Maximum power & $408 \mathrm{hp}$ \\
\hline Maximum velocity & $200 \mathrm{~km} / \mathrm{h}$ \\
\hline Acceleration $(0-100 \mathrm{~km} / \mathrm{h})$ & $6 \mathrm{~s}$ \\
\hline Time of fast charging & $5 \mathrm{~h} *$ \\
\hline Time of normal charging & $10 \mathrm{~h}$ \\
\hline Range & $400 \mathrm{~km}$ \\
\hline \multicolumn{2}{|c|}{ *for charger with $22 \mathrm{~kW}$ power } \\
\hline
\end{tabular}

BMW is a German car company that was founded in 1916. The production includes two models of electric cars: i3 and i8. The i3 model (Fig. 9) will be described. It has been in production since 2013 and belongs to minivan vehicles. According to ACEA (European Automobile Manufacturers Association), in 2017 it was the second most-bought electric car model in Poland [14].

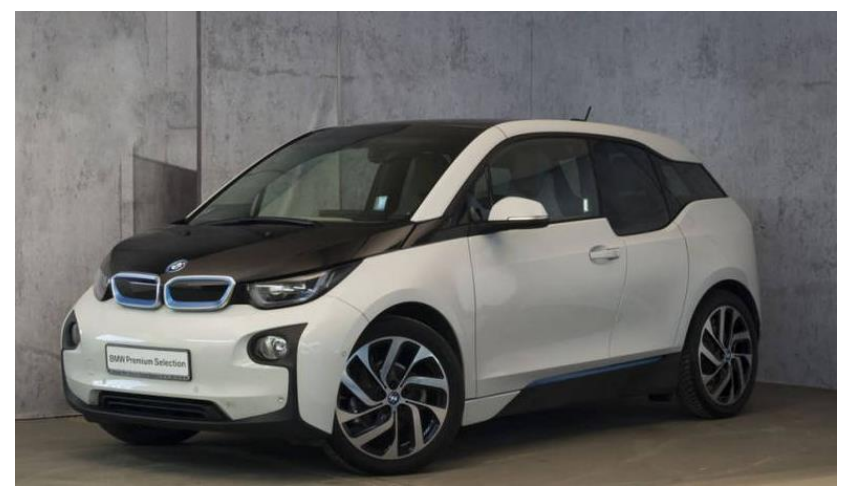

Fig. 9. BMW i3 [10]

Table 6 contains the basic technical data for the BMW i3 drive. The battery capacity is $33 \mathrm{kWh}$. The car can be charged in about 45 minutes, with a quick charger up to about $80 \%$. The maximum power that can be obtained 170 $\mathrm{hp}$. The vehicle accelerates to $100 \mathrm{~km} / \mathrm{h}$ in about 7 seconds, and the maximum speed that it can reach is $150 \mathrm{~km} / \mathrm{h}$. Batteries allow the range of the car for about $300 \mathrm{~km}$.

Table 6. Technical data for BMW i3 [10]

\begin{tabular}{|l|c|}
\hline Type of data & Value \\
\hline Battery capacity & $33 \mathrm{kWh}$ \\
\hline Maximum power & $170 \mathrm{hp}$ \\
\hline Maximum velocity & $150 \mathrm{~km} / \mathrm{h}$ \\
\hline Acceleration $(0-100 \mathrm{~km} / \mathrm{h})$ & $7.2 \mathrm{~s}$ \\
\hline Time of fast charging & $45 \mathrm{~min}$ \\
\hline Time of normal charging & $3 \mathrm{~h} 45 \mathrm{~min}$ \\
\hline Range & $300 \mathrm{~km}$ \\
\hline
\end{tabular}

Jaguar I-PACE S is the first car in this brand's electric car (Fig. 10). The Jaguar company was founded in 1922 and is a British brand owned by the Tata Motors group. The manufacturer's goal was to construct an electric car with high performance. This model is equipped with two electric 
motors. The premiere of Jaguar I-PACE was launched in March 2018. Jaguar I-PACE is an SUV.

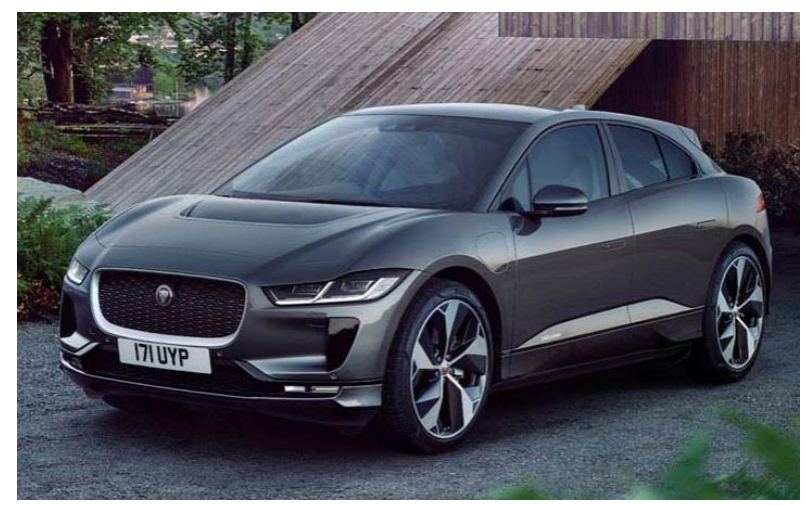

Fig. 10. I-PACE S Jaguar [11]

Technical data provided by the car manufacturer is shown in Table 7. The battery capacity is very large, it is $90 \mathrm{kWh}$. Obtained power is $400 \mathrm{hp}$, and the maximum speed that can reach a car is $200 \mathrm{~km} / \mathrm{h}$. The fully charged vehicle provides a range up to $470 \mathrm{~km}$. With a fast charger, the car can be charged up to $80 \%$ in about 2.5 hours.

Table 7. Technical data for Jaguar I-PACE [11]

\begin{tabular}{|l|c|}
\hline Type of data & Value \\
\hline Battery capacity & $90 \mathrm{kWh}$ \\
\hline Maximum power & $400 \mathrm{hp}$ \\
\hline Maximum velocity & $200 \mathrm{~km} / \mathrm{h}$ \\
\hline Acceleration $(0-100 \mathrm{~km} / \mathrm{h})$ & $4,8 \mathrm{~s}$ \\
\hline Time of fast charging & $2 \mathrm{~h} 30 \mathrm{~min}$ \\
\hline Time of normal charging & $12 \mathrm{~h}$ \\
\hline Range & $470 \mathrm{~km}$ \\
\hline
\end{tabular}

The next discussed model is a Tesla brand car (Fig. 11). This is an American manufacturer of fully electric cars. The company was founded in 2003. Tesla manufactures just 4 models of electric cars. This model - Tesla 3 is the newest and is in production from 2018. It is a medium-class sedan car.

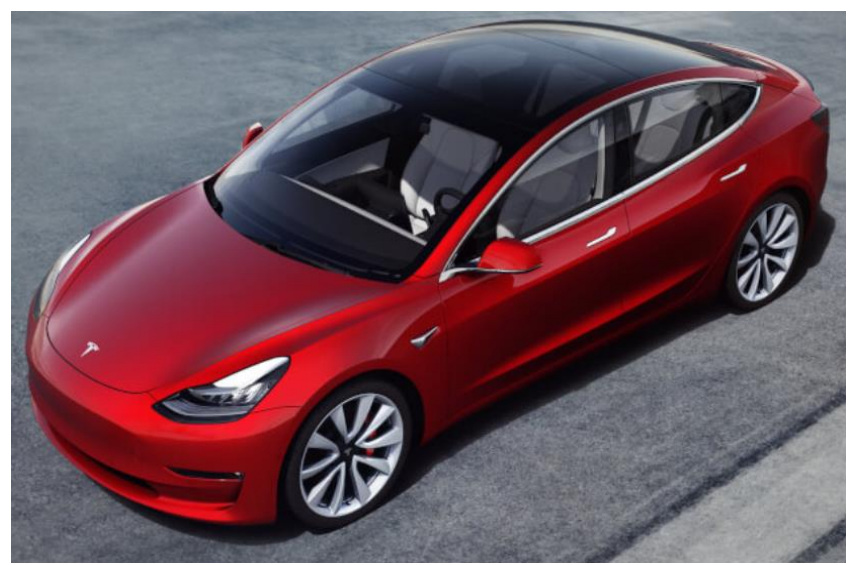

Fig. 11. Tesla 3 [12]

Technical data provided by the manufacturer is included in Table 8 . The vehicle has $80 \mathrm{kWh}$ batteries, and the maximum power provided by the electric engine is $257 \mathrm{hp}$.
When the car is $100 \%$ charged, this model has a range of about $500 \mathrm{~km}$. Charging time Tesla 3 with charger with capacity about $40 \mathrm{~kW}$ take one and a half hours. The car achieves a top speed of around $250 \mathrm{~km} / \mathrm{h}$, while the speed of $100 \mathrm{~km} / \mathrm{h}$ can develop in about 3 seconds.

Table 8. Technical data for TESLA 3 [12]

\begin{tabular}{|l|c|}
\hline Type of data & Value \\
\hline Battery capacity & $80 \mathrm{kWh}$ \\
\hline Maximum power & $257 \mathrm{hp}$ \\
\hline Maximum velocity & $250 \mathrm{~km} / \mathrm{h}$ \\
\hline Acceleration $(0-100 \mathrm{~km} / \mathrm{h})$ & $3.3 \mathrm{~s}$ \\
\hline Time of fast charging & $1 \mathrm{~h} 30 \mathrm{~min}$ \\
\hline Time of normal charging & $8 \mathrm{~h}$ \\
\hline Range & $499 \mathrm{~km}$ \\
\hline
\end{tabular}

\section{Comparison of available solutions for electric cars}

Analyzing commercially available solutions for fully electric cars, the most important aspects taken into account are the price of the car and of its maintenance, e.g. the cost of one full charge of the car. An important feature of this type of vehicle is also the possible range and speed. In Poland, the largest charging network for electric cars is Greenway. According to data from the Greenway report for 2018, there are currently 115 charging stations in Poland. They are 85-100 km apart (Fig. 12), and the sum of energy is $350 \mathrm{kWh}[4]$.

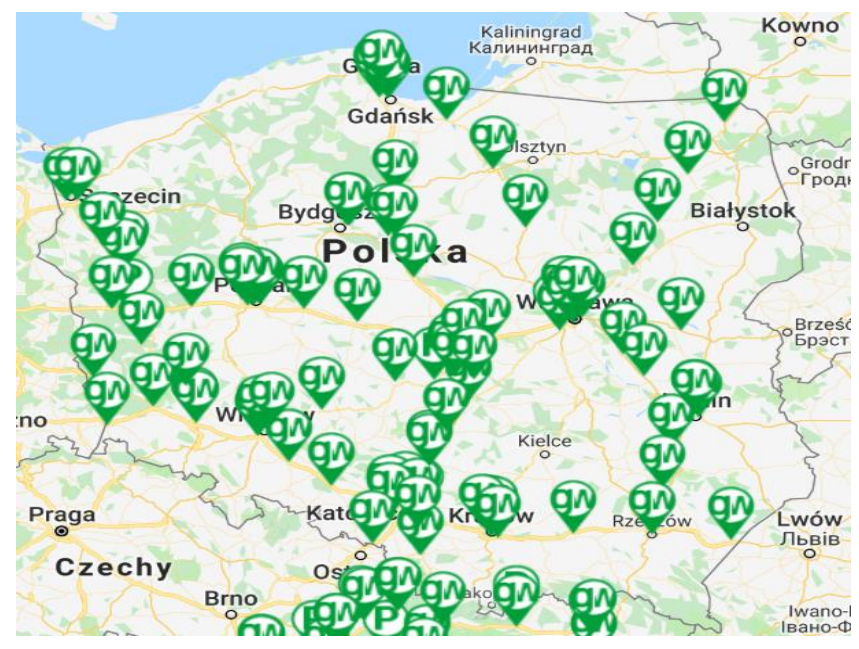

Fig. 12. Location of electric car charging stations in Poland [4]

Currently, chargers in Poland have a charging power of $40 \mathrm{~kW}$, which significantly increases the time of charging the car. The Greenway company plans to introduce 136 new chargers by 2020 , mainly fast $(50-150 \mathrm{~kW})$ and ultrafast $(350 \mathrm{~kW})$ [4]. These changes will enable charging of electric vehicles in a much shorter time. When analyzing the "cost-effectiveness" and costs associated with having an electric car, should refer to the price list of services provided by Greenway (Fig. 13).

Based on the Greenway price list and technical data for a given electric car model (Table 9), it is possible to calculate the costs of its use. 

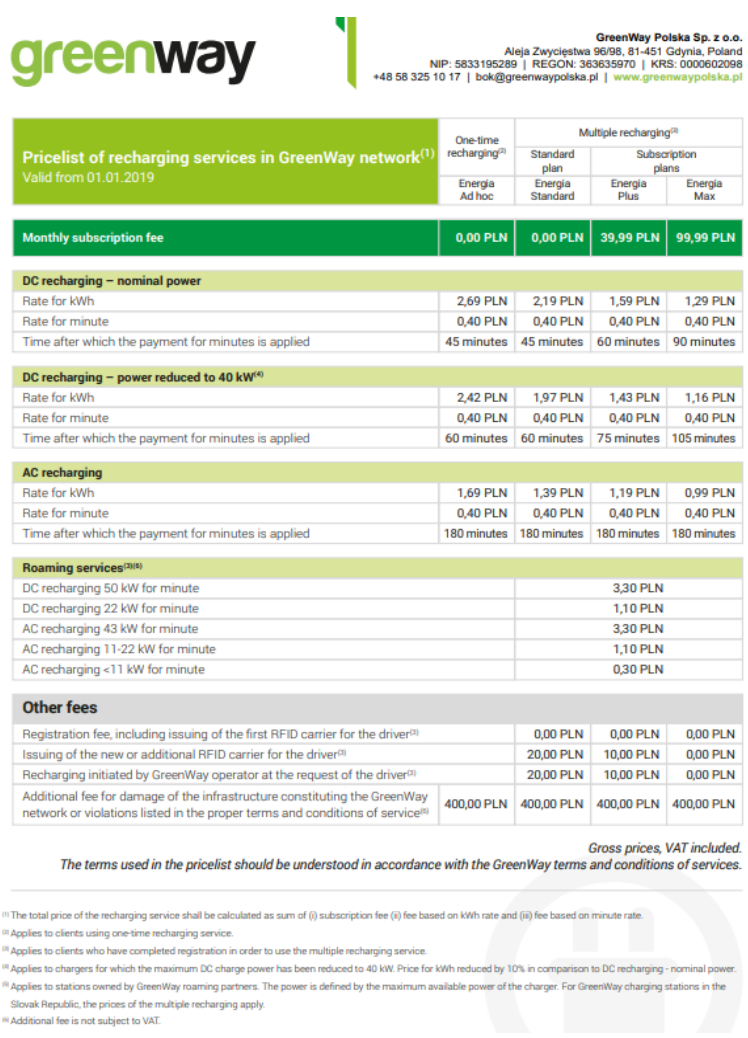

Fig. 13. Price list of Greenway's services [4]

Table 9. Collected data to the analysis [5-12]

\begin{tabular}{|l|c|c|c|c|}
\hline $\begin{array}{l}\text { Model of electric } \\
\text { vehicle }\end{array}$ & $\begin{array}{c}\text { Battery } \\
\text { capacity } \\
{[\mathrm{kWh}]}\end{array}$ & $\begin{array}{c}\text { Max. } \\
\text { power } \\
{[\mathrm{HP}]}\end{array}$ & Price [PLN] & $\begin{array}{c}\text { Max. } \\
\text { velocity } \\
{[\mathrm{km} / \mathrm{h}]}\end{array}$ \\
\hline $\begin{array}{l}\text { Hyundai KONA } \\
\text { electric }\end{array}$ & 64 & 204 & 136000 & 167 \\
\hline Renault ZOE & 41 & 92 & 132000 & 135 \\
\hline Tesla 3 & 55 & 257 & 255000 & 250 \\
\hline $\begin{array}{l}\text { I- PACE S } \\
\text { Jaguar }\end{array}$ & 90 & 400 & 356500 & 200 \\
\hline Nissan LEAF & 40 & 150 & 155500 & 140 \\
\hline $\begin{array}{l}\text { Volkswagen } \\
\text { e-GOLF }\end{array}$ & 36 & 134 & 187500 & 150 \\
\hline BMW i3 & 33 & 170 & 165000 & 150 \\
\hline Audi e-TRON & 95 & 408 & 360000 & 200 \\
\hline $\begin{array}{l}\text { Model of electric } \\
\text { vehicle }\end{array}$ & $\begin{array}{c}\text { Cost per } \\
100 \mathrm{~km}\end{array}$ & $\begin{array}{c}\text { Range } \\
\text { (WLTP) }\end{array}$ & $\begin{array}{c}\text { Time of } \\
\text { charging } \\
\text { for } 7.2 \mathrm{~kW} \\
\text { charger })\end{array}$ & $\begin{array}{c}\text { Time of } \\
\text { charging } \\
\text { for } 40 \mathrm{~kW} \\
\text { charger) }\end{array}$ \\
\hline $\begin{array}{l}\text { Hyundai KONA } \\
\text { electric }\end{array}$ & 16.2 & 470 & 9.7 & $2 \mathrm{~h}$ \\
\hline Renault ZOE & 16.1 & 300 & 7.4 & $65 \mathrm{~min}$ \\
\hline Tesla 3 & 18.58 & 310 & 8.25 & $1 \mathrm{~h} \mathrm{30} \mathrm{min}$ \\
\hline $\begin{array}{l}\text { I- PACE S } \\
\text { Jaguar }\end{array}$ & 25.9 & 470 & 12.7 & $2 \mathrm{~h} \mathrm{30} \mathrm{min}$ \\
\hline Nissan LEAF & 12.2 & 380 & 6.5 & $60 \mathrm{~min}$ \\
\hline $\begin{array}{l}\text { Volkswagen } \\
\text { e-GOLF }\end{array}$ & 9.8 & 300 & 6 & $60 \mathrm{~min}$ \\
\hline BMW i3 & 15.2 & 300 & 3.75 & $45 \mathrm{~min}$ \\
\hline Audi e-TRON & 18 & 400 & 10 & $5 \mathrm{~h} *$ \\
\hline
\end{tabular}

Table 9 contains the data necessary to perform the analysis: the amount of $\mathrm{kWh}$ consumed per $100 \mathrm{~km}$ by each of the car models, their range, battery capacity and charging time. To perform the characteristics, the maximum speed of the vehicle model, maximum power and price will also be used. Detailed calculations will be carried out for one model - Renault ZOE, and the remaining results compiled in the form of characteristics. The range of the car is the results of tests in accordance with WLTP (Worldwide harmonized Light duty vehicle Test Procedure) [15], which is a cycle of research on $\mathrm{CO}_{2}$ emission standards, fuel consumption and energy consumption. WLTP tests were introduced in 2017. From that date all cars with the new homologation have values according to WLTP, and from 1 September 2018, all registered vehicles will require WLTP entries [13].

Being a Renault ZOE user (selected for detailed analysis), the costs related to use will be as follows:

- subscription purchase: it is assumed that the user performs full registration and subscribes to Energy standard, which monthly costs 0.00 PLN,

- it is assumed to charge the vehicle with direct current (DC) - with the charger power reduced to $40 \mathrm{~kW}$ (such chargers most often occur in Poland).

- Cost of charging vehicle Renault ZOE up to $100 \%$

$$
\mathrm{C}_{100 \%}=\mathrm{P}_{\mathrm{A}} \cdot \mathrm{C}_{1 \mathrm{kWh}}+\left[\left(\mathrm{T}_{\text {char }}-60\right) \cdot \mathrm{C}_{\text {LIMIT }}\right]
$$

where: $\mathrm{C}_{100 \%}-$ cost of charging vehicle up to $100 \%, \mathrm{P}_{\mathrm{A}}-$ capacity of battery $[\mathrm{kWh}], \mathrm{C}_{1 \mathrm{kWh}}-$ cost for $1 \mathrm{kWh}$ charging in energy standard subscription, $\mathrm{T}_{\text {char }}$ - time of charging with $40 \mathrm{~kW}$ voltage charger, $\mathrm{C}_{\text {LIMIT }}$ - cost of one minute charging after exceed the time limit - in Energia standard subscription after $60 \mathrm{~min}$

$$
\mathrm{C}_{100 \%}=41 \cdot 1.97 \cdot[(65-60) \cdot 0.40]=82.77 \mathrm{PLN}
$$

- Cost of overpower $100 \mathrm{~km}$ by vehicle

$$
\mathrm{C}_{100 \mathrm{~km}}=\mathrm{W} \cdot \mathrm{C}_{1 \mathrm{kWh}}
$$

where: $\mathrm{C}_{100 \mathrm{~km}}$ - cost for overcome $100 \mathrm{~km}$ by each car model, $\mathrm{W}$ - number of $\mathrm{kWh}$ necessary to overcome 100 $\mathrm{km}, \mathrm{C}_{1 \mathrm{kWh}}-$ cost for $1 \mathrm{kWh}$ charging in Energia standard subscription.

$$
\mathrm{C}_{100 \mathrm{~km}}=16.1 \cdot 1.97=3.72 \mathrm{PLN}
$$

Based on the results, it can be said that users will pay about 83 PLN for driving $300 \mathrm{~km}$ (city driving). For comparison, for $300 \mathrm{~km}$, for example Volkswagen Polo, which consumes approximately 7 liters of gasoline for every 100 $\mathrm{km}$, the user will incur costs equal to:

$$
\mathrm{C}_{\mathrm{VW}}=\mathrm{S} \cdot \mathrm{W}_{\mathrm{l} / 100 \mathrm{~km}} \cdot \mathrm{C}_{\mathrm{G}}=3 \cdot 7 \cdot 4.8 \approx 100 \mathrm{PLN}
$$

where: $\mathrm{C}_{\mathrm{VW}}$ - cost of overcome $300 \mathrm{~km}$ with Volkswagen Polo vehicle, $\mathrm{S}$ - road to overcome, $\mathrm{W}_{\mathrm{l} / 100 \mathrm{~km}}$ - volume of gasoline consumed by vehicle per $100 \mathrm{~km}, \mathrm{C}_{\mathrm{G}}-$ cost of gasoline.

As can be seen, the result is comparable. The calculations presented were made for all the models discussed, and the results will be presented in the form of characteristics (Figs 14 and 15).

Figure 14 shows the cost of moving $100 \mathrm{~km}$ of the electric vehicle models. These costs reach values between 20 and 50 PLN. The lowest cost and at the same time comparable to the price of moving a car with gasoline-powered combustion engine (green color) is characteristic for 
Volkswagen e-GOLF and Nissan LEAF cars. In the case of these two models, the price per $100 \mathrm{~km}$ is $19.31 \mathrm{PLN}$ and 34.03 PLN respectively. The least profitable types of electric vehicles are SUV cars - Audi e-TRON and Hyundai KONA, for which the cost for covering a distance of 100 $\mathrm{km}$ is 35.46 and 31.91 PLN, respectively. The most expensive in operation are cars reaching high values of maximum power and maximum speed - I-PACE Jaguar and Tesla 3 (red color). However, it should be noted, that the price per $100 \mathrm{~km}$ for Hyundai KONA electric and Renault ZOE is very similar, although these are two very different types of cars. This means that Hyundai KONA, which is an SUV, is characterized by low costs, in terms of its type.

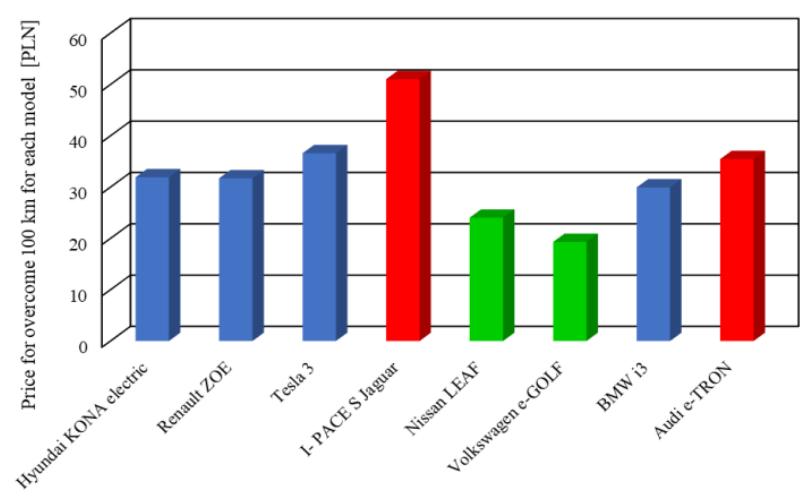

Fig. 14. The price for overcome $100 \mathrm{~km}$ for each model

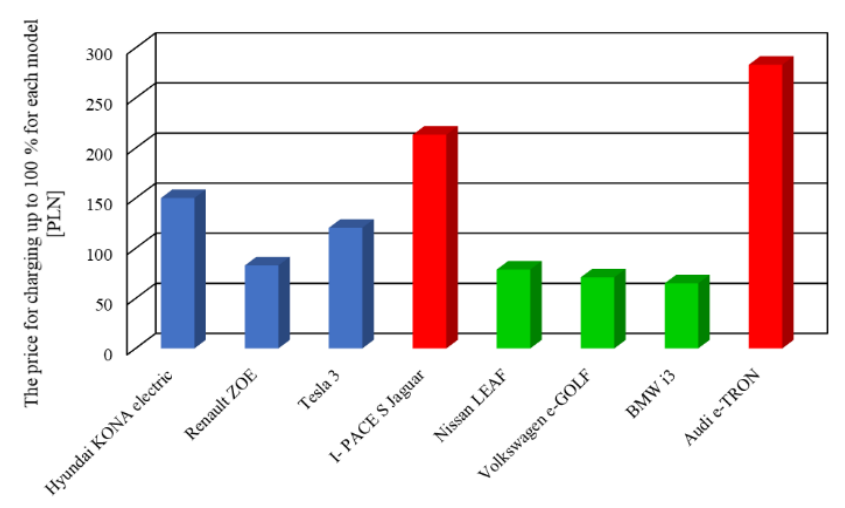

Fig. 15. Price for charging up to $100 \%$ for each model

Also, a differentiated charge for up to $100 \%$ of selected vehicle types was analyzed (Fig. 15). The lowest price, when loaded up to $100 \%$, is modeled on small passenger cars - Volkswagen e-GOLF, Nissan LEAF and BMW i3 (green color). The range of costs for one charging is from 65 to about 80 PLN. The least favorable results concern IPACE Jaguar and Audi e-TRON vehicles. In both cases, the price for a full charge differs significantly from the price for the other models and amounts to 213 and 283 PLN. Comparing the two SUV models - Hyundai KONA and Audi e-TRON, it can be seen a significant difference in the cost of use. The Hyundai brand car is about 130 PLN cheaper, despite the similar charging time. This is caused by a significant difference in the capacity of batteries for individual models (64 and $95 \mathrm{kWh}$ ). This affects the whole of the obtained results, hence their difference compared to those obtained during the analysis of the costs of covering a distance of $100 \mathrm{~km}$.

The other characteristics created on the basis of the data from table 9 will be performed to make a more detailed analysis. Figure 16 shows two relations: maximum range (according to WLT) for individual car models and charging time up to $100 \%$ for a $40-\mathrm{kW}$ charger. The largest range is provided by Hyundai, Audi and Jaguar. Can be seen with a long range, these models are characterized by longer charging times.

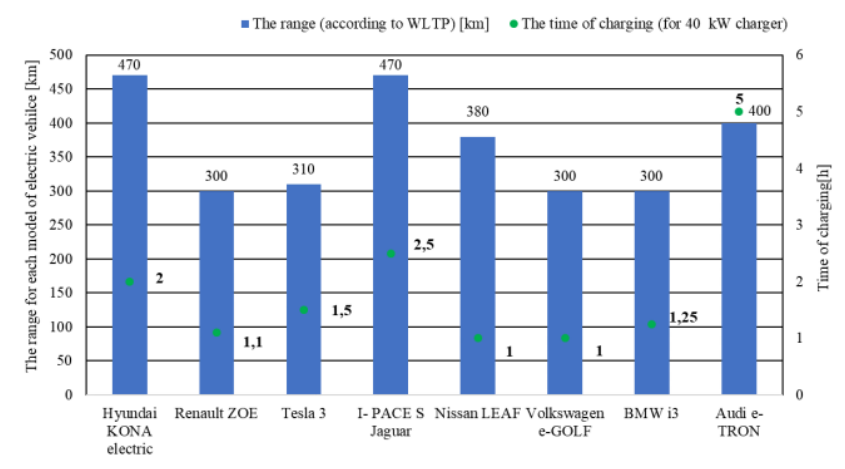

Fig. 16. The range and time of charging for each model

However, the shortest range and the shortest charging times are characterized by the following models: Volkswagen e-GOLF, BMW i3 and Renault ZOE. The most advantageous model at this stage of the analysis is the Nissan LEAF, which, after a full charge, lasting one hour, can provide a range of around $380 \mathrm{~km}$. Tesla 3, on the other hand, despite high maximum power and high performance, can only beat $310 \mathrm{~km}$ on a single charge. This may be due to the lower capacity of the battery than in the case of models such as Audi e-TRON, or I-PACE Jaguar, having a battery capacity of about $90 \mathrm{kWh}$. In the case of Audi, the charging time shown is for a $22 \mathrm{~kW}$ charger (no manufacturer's information about charging time for a $40 \mathrm{~kW}$ charger). It can therefore be assumed that with a $40 \mathrm{~kW}$ charger, this time would be about 2.5 hours or up to a maximum of 3 hours. Based on this assumption, it should be noted that the charging time of the Audi e-TRON model is similar to the other models with a range of around 400/500 $\mathrm{km}$.

The next discussed characteristic is the comparison of the range of individual models and their maximum power depending on the capacity of the batteries. It can be seen, the maximum power depends on the capacity of the accumulators (Fig. 17).

The models of cars with high capacity batteries (in $\mathrm{kWh}$ ) provide vehicles with high maximum power values. Models such as Audi e-TRON and I PACE Jaguar, which have accumulators with a power of about $90 \mathrm{kWh}$, obtain maximum power at $400 \mathrm{hp}$. It should be noted that the Hyundai electric model, despite the greater capacity of batteries than the Tesla 3 car, is characterized by much lower maximum power.

It may be affected by the torque of the engine installed in these models. Smaller vehicles, mainly intended for urban driving (Nissan, Volkswagen or Renault), achieve the 
most favorable results in the analysis. They have the lowest prices, their charging, thanks to the smaller capacity of batteries and lower maximum powers, is short, while providing a relatively large range. The Nissan LEAF is by far the best-performing model of an electric car, taking into account all the factors discussed, which also confirms the popularity of this model - in 2018 it was the most-bought fully electric car.

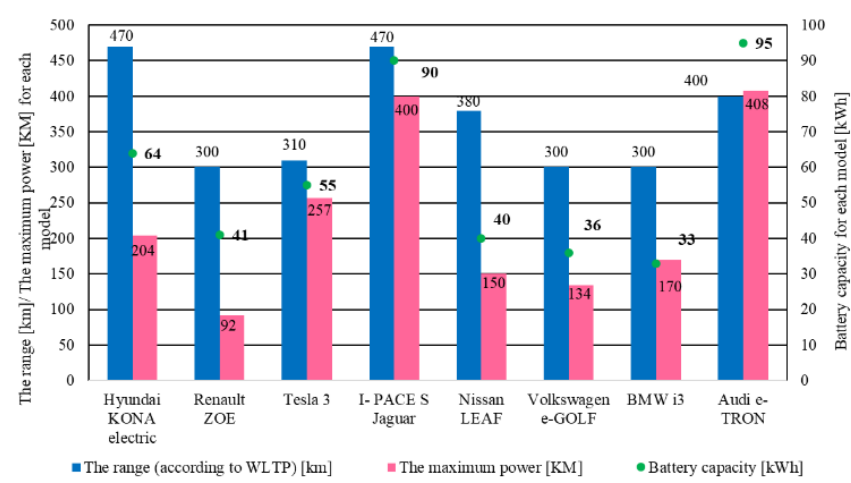

Fig. 17. The range, maximum power and battery capacity for each model

\section{Conclusions}

The increasingly restrictive standards regarding the emission of toxic exhaust components cause an increase in interest in means of transport with alternative propulsion sources. The article analyzes the available of cars with electric propulsion on the market. The latest and most frequently purchased models of electric cars were selected for the analysis. When making a comparison in the costs of use and basic technical parameters, no conclusive results were obtained. Referring to the costs: smaller electric cars, serving mainly for city driving, will generate similar costs as cars with internal combustion engines.

However, larger cars-e.g. SUVs generate significantly higher costs of use than cars with an internal combustion engine. Comparing the technical data of individual models, the following conclusions can be made:

- Nissan LEAF, Volkswagen e-GOLF, and Renault ZOE have much worse performance than similar types of vehicles with internal combustion engines,

- Tesla or Jaguar cars are characterized by very good performance, but their use is much more expensive than similar vehicles with internal combustion engines.

In the use of electric cars, the availability of charging points is very important. In Poland, in recent years, many stations have been built, but they are not well equipped. Only a small number of stations have chargers for quick charging. This is important, especially for high-powered cars. Then the charging time using the DC charger is significantly longer. Such situation has a negative impact on the increased sales of electric cars in Poland. To summarize, the availability of fully electric cars on the market is increasing. More and more car manufacturers are choosing to produce cars with fully electric drives. Small city cars, SUVs and sports cars can be found on the market. This shows that electric cars are very popular with the public and greatly affect the development of this type of vehicles.

\section{Bibliography}

[1] PIELECHA, I., CIEŚLIK, W., BOROWSKI, P. et al. Rozwój silników spalinowych napędów hybrydowych. Combustion Engines. 2014, 158(3).

[2] www.rp.pl/

[3] TARKOWKI, P., SIEMIONEK, E. Układy napędowe pojazdów elektrycznych. Postępy Nauki i Techniki. 2010, 5.

[4] www.greenwaypolska.pl

[5] https://www.hyundai.pl/

[6] https://www.renault.pl/

[7] https://www.nissan.pl/

[8] www.volkswagen.pl/

[9] www.audi.pl/

[10] www.bmw.pl/

[11] www.jaguar.pl/

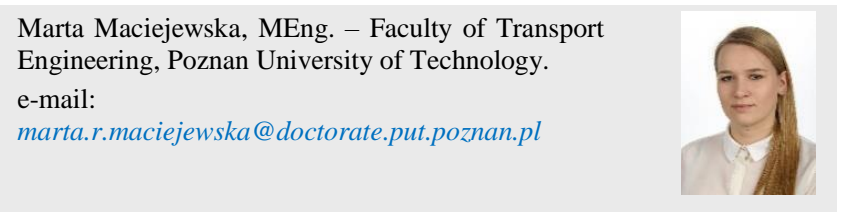

[12] www.tesla.com/

[13] http://www.skoda-auto.pl/technologia/wltp

[14] GALANT, M., NOWAK, M., MACIEJEWSKA, M. et al. Using the simulation technique to improve efficiency in General Aviation. AIP conference proceedings. 2019, 2078(1), 020097.

[15] PIELECHA, J., KURTYKA, K., SKOBIEJ, K. The impact of vehicle dynamic parameters on the exhaust emission in RDE tests. Combustion Engines. 2018, 175(4).

[16] FUĆ, P., LIJEWSKI, P., ZIÓŁKOWSKI, A., SIEDLECKI, $M$. Trends in the type-approval regulations in terms of exhaust gas emissions for vehicles of category PC and LDV. Combustion Engines. 2015, 162(3).

Paweł Fuć, DSc., DEng. - Professor in the Faculty of Transport Engineering at Poznan University of Technology.

e-mail:pawel.fuc@put.poznan.pl

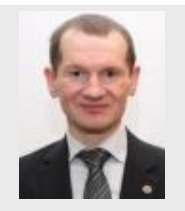

Monika Kardach, MEng. - Faculty of Transport Engineering, Poznan University of Technology.

e-mail:

monika.t.kardach@doctorate.put.poznan.pl

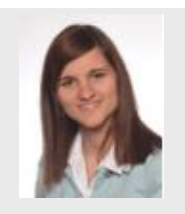

